\title{
MAKING EXTENSIVE READING EVEN MORE STUDENT CENTERED
}

\author{
George M. Jacobs \\ James Cook University, Singapore \\ email: george.jacobs@jcu.edu.au \\ Willy A. Renandya \\ Nanyang Technological University, Singapore \\ email:willy.renandya@nie.edu.sg
}

Article received: 21 July 2014

Final proof received: 4 December 2014

\begin{abstract}
This article begins by explaining the student centered learning paradigm. Next, the article explains various features of a student centered approach to education and how extensive reading (ER), as it is most often practiced, fits with those features. The bulk of the article suggests how ER might be implemented to make it even more learner centered.
\end{abstract}

Keywords: Extensive reading, learner centered, paradigm, schema, positivism, postpositivism

Humans tend to see the world in patterns, or schema, that we develop based on our experiences and innate characteristics (Ausubel, 1968). Our brains search for, generate, and recognize such patterns, e.g., we have patterns for using rice cookers and riding public buses. "Paradigms" are similar to patterns, but according to Kuhn (1996, p. $10)$, paradigms are broader, and "for a time, provide model problems and solutions for a community of practitioners".

Kuhn (1962) first studied paradigms in the physical sciences, particularly how paradigms change. He argued that new paradigms develop when scientists recognize that the currently dominant paradigm no longer works to explain reality. Famous examples of what are called paradigm shifts are Ptolemeian to Copernican astronomy and from Newtonian to quantum physics. In addition to the physical science, paradigm shifts occur in many other realms of society, e. g., the art world witnessed a shift from Realism to Abstract Expressionism.

Education has also experienced a paradigm shift, as part of a larger societal paradigm shift from positivism to postpositivism (Berman, 1981; Capra, 1983). Table 1 (from Jacobs \& Farrell, 2001) contrasts positivism and post-positivism.

Table 1: Contrasts between positivism and post-positivism

\begin{tabular}{l}
\hline Positivism \\
\hline Emphasis on parts and decontextualization, Emphasis on whole and contextualization \\
e.g., studying grammar or vocabulary in \\
isolated sentences, instead of in whole texts \\
Emphasis on separation, e.g., studying Emphasis on integration, e.g., ESP \\
language skills, such as reading and (English for Specific Purposes) courses \\
speaking, as separate courses, and separation that combine learning content, such as \\
of students' lives from what is studied in Business, with learning language \\
school \\
Consideration only of the objective and the Consideration also of the subjective and
\end{tabular}


quantifiable, e.g., measuring success only by exam scores

Reliance on experts and outsider knowledge-researcher as external, e.g., valuing what professors say about how to do education

Knowledge is relatively fixed, with teachers' task being to transmit that knowledge to students, and students' task being to absorb that knowledge; teachers and students do not develop knowledge

Focus on teacher control, e.g., valuing a quiet classroom, where only one person, usually the teacher, is talking

Top-down, e.g., all decisions are made by administrators or teachers

Attempts to standardize, e.g., using the same teaching method all the time, and using the same materials with all students

Focus on the product and the short-term, e.g., students' scores on tests of reading at the end of the term or year

the non-quantifiable, e.g., also measuring success by students' feelings and attitudes Consideration also of the "average" participants and insider knowledge-researcher as internal, e.g., also valuing teachers' and students' views

Knowledge changes, and what we thought we knew may actually be wrong; teachers and students have a part in the process of questioning and developing knowledge

Focus on student control, as in the final analysis, students are the ones who do the learning

Bottom-up, e.g., students' voices are heard by teachers, administrators, and peers, and teachers' voices are heard by administrators

Appreciation of diversity, e.g., modifying teaching to include varied and diverse methods and materials for different students

Focus on the process as well, e.g., strategies students can use as they read now and long into the future, in their first language and in other languages

In education, the paradigm shift from the positivism to post-positivism shift saw a shift from behaviorist psychology toward socio-cognitive psychology, also known as social constructivism. The new paradigm in education has been called by such names as student centered learning, learner centered learning, active learning, personalized learning, engaged learning, and child centered learning. This article uses the term Student Centered Learning (SCL). Central to SCL is the view that students, not teachers or materials, are the keys to what and how much learning takes place. Some features of SCL are listed below. After each feature, in brackets, is a link to the post-positivist paradigm.

1. Student control (Du, 2012; Knowles, 1975; Mayr, 2012): Offering students more control of their own learning acknowledges students' pivotal role, with the hope that greater agency will increase students' engagement in their own learning. [Focus on student control and bottom-up voices.]

2. Learning to learn (Brown, 2014; Torres, 2013; Tseng, Dornyei, \& Schmitt, 2006): The learning process and acquisition of learning strategies, i.e., learning how to learn, is more important than short term results, such as test scores, although results also matter. The use of thinking skills provides important strategies for lifelong learning. [Focus on the process rather than only on the product.]

3. Learning with peers (Cohen \& Lotan, 2014; Jacobs \& Kimura, 2013; Johnson, Johnson, \& Holubec, 2008): Part of students having more control and part of students learning how to learn involves learning with peers, not as the only way to learn, but as an important stimulus of learning. Learning with peers includes acquiring the skills and attitudes needed to interact with others. [Focus on emotions, e.g., caring about others and 
feeling part of a group; student control; e.g., students are responsible for their own learning and that of their peers; appreciation of the learning process, e.g., developing strategies for learning with peers, strategies that can be used well after students' formal education has ended.]

4. Diversity (Banks, Cookson, Gay, \& Hawley, 2001; Gardner, 1993; Johnson \& Johnson, n.d.): Part of the focus on students as the key to learning involves understanding that students differ from one another and coming to appreciate that differences can facilitate rather than hinder learning. [Appreciation of diversity and an eagerness to include students' voices.]

5. Connections to students' worlds (Boss, 2014; Freire, 1970; Kumasi, 2014): SCL seeks to include students' needs and interests in the curriculum, e.g., by connecting the curriculum to students' lives outside of school. [Consideration of the average participants. Teachers and students' voices are considered, rather than only those of outside experts. Learning is contextualized and integrated with students' lives and interests.]

6. Teachers as fellow learners (FeimanNemser, 2012; Hill, Ball, \& Schilling, 2008; Jacobs \& Farrell, 2001). Teachers do not pose as all knowing sages. Instead, they show students that teachers too need to learn and that they enjoy learning. [Teachers and students have a role in questioning and developing knowledge. The joy of learning embraces the subjective side of education.]

7. Motivation and the self (Dornyei \& Ushioda, 2009; Kim, 2011; Renandya, 2014): Learners who develop a powerful image of their ideal future selves and seek to acquire and use tools to realize their ideal future self are more likely to achieve success in their learning. [Inclusion of the subjective and appreciation of feelings.]

The next section of this article looks at one SCL inspired teaching method, i.e., extensive reading, and how it matches the seven features of SCL explained above.

\section{EXTENSIVE READING AND STUDENT CENTERED LEARNING}

This second section of the article briefly explains extensive reading (ER) and discusses how ER as, to the authors' understanding, it is most often done, embodies characteristics of the SCL paradigm. Learners do ER when they read in quantity (Day \& Bamford, 1998; Extensive Reading Foundation, 2011; Jacobs \& Farrell, 2012). ER derives support from a body of research that is wide in terms of geographic range, age of learners, reading levels of learners, and languages being learned (Extensive Reading Foundation, 2014; Krashen, 2011). Overall, this research suggests many cognitive, linguistic and affective benefits for the use of ER, such as enhanced skill in reading, grammar, spelling, and writing, and greater confidence in reading ability (Anderson, 1996; Renandya, 2007). Indeed, Bamford \& Day (2004) stated, 'Good things happen to students who read a great deal in the foreign language. Research studies show they become better and more confident readers, they write better, their listening and speaking abilities improve, and their vocabularies get richer. In addition, they develop positive attitudes toward and increased motivation to study the new language' (p. 1). Given the significant benefits of ER, it is understandable that ELT experts, such as Alan Maley (2005), regard ER as 'the single most important way to improve language proficiency' (p. 354).

Below, ER is discussed with reference to the seven SCL characteristics explained in previous sections of this article.

1. Student control: Typically, in ER, students choose what they will read from what is available in their classrooms, in libraries, bookshops, and increasingly, online. Indeed, another term for ER is Free Voluntary Reading (Mason, 2006). Students can select books that are at or slightly below/above their levels. They 
can also read materials that are far below their current reading levels in order to further increase their reading confidence. Incidentally, reading easy books may also have other benefits. Research suggests that reading easy books can facilitate students' reading fluency (O'Shea, Sindelar, \& O'Shea, 1985), a necessary element in their overall reading competence. Student choice is often guided, e.g., the books in a school library may be grouped by difficulty level. Also, teachers may encourage students to spend time reading a book before the students decide whether they want to borrow it from a library.

2. Learning to learn: ER may often be paired with Intensive Reading (IR). In IR, students read materials that may be difficult for them to understand on their own. Thus, IR materials tend to be short, and an entire class may read the same material at the same time, with instruction by teachers to enhance students' understanding. During IR, teachers often offer instruction in the use of relevant strategies, such as guessing word meaning from context, summarizing, and connecting what is being read to one's own experiences. These strategies assist students when they do ER. As a result, IR and ER can complement one another.

3. Learning with peers: To our knowledge, peer interaction is not a standard part of ER programs. Instead, students read on their own and most often work alone to do post reading activities, if any are required, and post reading activities of some kind usually are part of ER programs.

4. Diversity: ER fits well with the idea of catering to students' diverse interests, because students can choose to read those materials which interest them. For instance, students who enjoy non-fiction can select such books, whereas students who prefer fantasy can read fantasy books. Also, students can choose reading materials that fit their current reading levels.
5. Connections to students' worlds: Fortunately, the range of commercially available materials for ER, at least in English, continues to grow. However, as materials tend to be written for international audiences, students may have difficulty finding materials that reflect the world in which they live. Furthermore, materials written even one or two years earlier may not be in close step with current issues. Yes, ER done with materials that speak of different times and places certainly does have value. The point here is that value can also be found in materials that match students' current situations, such as materials created locally, e.g., by teachers and students themselves.

6. Teachers as fellow learners: Many teachers' guides to ER recommend that teachers engage in silent reading along with students in order to demonstrate that teachers too read for learning and enjoyment (Day \& Bamford, 2002). Teachers may read materials that match students' reading levels and interests, or they may read materials that match teachers' own reading levels and interests.

7. Motivation and the self. Motivation is closely linked to ER. Many ER experts agree that motivation is a key ingredient of successful ER programs. Students will not read in quantity, and therefore will not gain the full benefits of ER, unless they can find reading materials that are cognitively and affectively appealing to them. The high level of enjoyment that students derive from their self-selected reading is often used as an indicator of success in ER (Day, 2011).

The next and final section of this article offers suggestions for enhancing the fit between SCL and ER.

\section{MAKING ER EVEN MORE STUDENT CENTERED}

The third and last section of this article suggests ways that ER can even better promote SCL. None of the suggestions 
below is original. The hope is that the ideas explained here can be used more widely. Also, the authors appreciate that learning contexts differ widely, and that what works in one context may not be appropriate in other contexts.

1. Student control: In addition to students selecting the books they will read, students can also have a role in selecting the books and other materials that make up the pool of materials from which students make their reading selections. In other words, students can have a role in deciding which books are in their classroom libraries and their school libraries. Here are examples of how this can happen.

a. If books are ordered from catalogues or purchased at book fairs, students can be involved in the selection process.

b. Students and their families can donate books, new or used. For instance, the donation can take place on students' birthdays. Alternatively, graduating students can donate books as a way of leaving something of themselves behind. Donated books can contain notes from the donors for future readers.

c. Students can find reading material on the web that might work for themselves and their peers.

2. Assessment of ER is another area in which students can exercise some control. Two areas under assessment are: (i) what students do for assessment tasks, and (ii) who assesses those tasks. While some experts (e.g., Krashen, 2011) argue against the routine use of tasks to accompany ER, others have suggested a wide array of possible tasks (Bamford \& Day, 2004; Burke, n.d.; Jacobs \& Farrell, 2012). Student control increases when students have a role in choosing which tasks they will do (including perhaps designing their own tasks), developing assessment criteria for those tasks, and participating in self and peer assessment, often in conjunction with teacher assessment. ER

Here are some tasks that can accompany

a. Give a review (can be oral or written) of the book to convince others to read or not read it.

b. Tell/Write about the most interesting/important/exciting part of the book.

c. Read aloud an interesting/ exciting/well-written part of the book. Perhaps, change your voice (e.g., accent, high/low, excited/sad) at various points while reading aloud.

d. Role play the story or parts thereof.

e. Tell about something you learned from the book. For example, you might have learned children's feeling when their parents pass away.

f. Use the knowledge gained from the book to do something. For example, if you read a book about badminton, you could use the book to play badminton better. Explain how the book helped you.

g. Design front and back covers for the book, with a drawing on the front and a summary/blurb on the back. An alternative to drawing would be graphics, photographs, words, colour designs, collages, and combinations of these.

h. Design a bookmark to suit the book. It can strictly be visual or it can contain words.

i. Paint a mural/draw illustrations/do a cartoon version of the book or of one part.

j. Create a mobile from a coat hanger, etc. The mobile can display information about the book, key ideas (or characters or events), and reactions to/ratings of the book.

k. Design a poster to advertise the book.

1. Draw/use a map to show important places/routes in the book. Explain why they are important. 
m. Draw a mind map or similar graphic organizer to represent what happens in the book.

n. Do a flow chart/story board of the events in the story.

o. Create a timeline of events in the book, perhaps with some text to help people understand the events in the timeline.

p. Do "Book in a Bag." After reading a book, decorate the outside of a paper bag to go with the book, and put various book-related items in the bag. Students present their bags to groupmates. Boxes, large envelopes, etc. can be used instead of bags.

q. Create a collage based on the book.

r. Do "Submarine Sandwich Books," adapted from http://www.educationworld.com/a_lesson/lesson/lesson109. shtml. Various aspects of the book are represented by different items that students use to make their sub sandwich. For example, the bread at the top can be the title and the bread at the bottom is the author. The sauce can be what the reader liked most about the book. Various other ingredients can be the plot, character, setting, and words learned. The moral of the activity: We're hungry for books!

s. Compare the book with a movie/TV version of the same book.

t. Read the same book in another language, e.g., if you speak English and are learning Spanish, read a book in English first and then in Spanish.

u. Read a different version of the same book, e.g., read a comic book or an abridged/simplified version and then read the unabridged version.

v. Read another book on the same topic and compare them, e.g., a biography and an autobiography of the same person.

w. Record an important segment of the book with the necessary introduction. The segment can be abridged in order to make it more interesting to listeners. Sound effects can be added. x. Look for websites related to the book and/or the author. When found, these websites can be shared with others via a class list or a post-it note in the book. Many authors nowadays have websites or webpages.

y. Write a poem inspired by the book. Remember that there are many simple poetry forms, such as acrostics.

z. Take a well-known song, nursery rhyme, etc. and make new words for it based on the book. Perform your song, etc. for others.

aa. Write an online review of the book for a website such as Amazon.

bb. Write a newspaper article, with a headline, about the events, characters, or information in the book. You could write a want ad or an editorial. The article could go in a real student publication.

cc. Tell about the character(s) you like best and why.

dd. Summarize and retell the story.

ee. Copy interesting words and expressions into a notebook. Do things with these words and expressions, such as define, illustrate via drawings, give examples, use them to communicate with other people, or create a crossword puzzle with them.

ff. Imagine you are a character in the story. Would you have made different decisions, said something differently and taken different actions? If you were the character in the present day, how would you behave differently?

gg. Imagine that a character in the story became a student at your school. How would they dress? How would they behave? How would students, teachers, you, and others react to them?

hh. Write an outline of a sequel to the story. A shorter form of this would be an epilogue that briefly tells what happened later to the book's characters and perhaps, aspects of the 
setting, e.g., a village where some of the characters lived.

ii. Write an outline of a prequel to the story.

jj. Use three words to describe the book, e.g., engaging, surprising, gripping.

kk. Write a short note to the next reader of the book, e.g., you might want to explain something that will help the next reader better appreciate the book. These notes will stay in the book to be read by all future readers. Perhaps an envelope can be attached to the inside front cover of the book to hold these notes. Similarly, a library pocket can be pasted onto the inside back cover and note cards can be placed in the pocket. Also, post-its can be used. The next reader can also write, to agree, disagree, or add to what earlier readers wrote, so that there is a dialogue about the book.

11. Write letters to one of the characters or from one character to another. If possible, find someone else who read the same book, and do an exchange with them. They reply as the character to whom you write, and you reply as the character to whom they write.

$\mathrm{mm}$. Write a letter to the author(s) of your book. And, nowadays, many authors have websites (their own or their publishers) to which you can send a letter/email and have some hope of a reply.

nn. Keep a reading response journal. Once a week, use the journal as a place to write about what you have read. Classmates and/or the teacher read and respond to your entries.

oo. Create an $\mathrm{ABC}$ book based on the book you read. You take each letter of the alphabet and come up with a significant word that begins with that letter. This could be a character's name, a place, or a word pertaining to a theme or emotion that takes place in the book. Then, students create some sort of book with one letter on each page with an explanation of the word that they chose. Each page should have some sort of illustration or decoration.

pp. Don't do anything; just get another book and start reading it.

3. Learning to learn: One category of learning strategies that might be bolstered in ER programs involves thinking skills (Ministry of Education Singapore, 2010). These skills could come into play before, during, and after reading. Examples of thinking skills and how they might be integrated with ER include:

a. Students keep a reading diary, in which they reflect on their reactions to what they read (Carlisle, 2000)

b. Students select from a range of thinking questions and respond to the selected question(s) before, during, or after reading. Bloom's Taxonomy of Educational Objectives (Bloom, Engelhart, Furst, Hill, \& Krathwohl, 1956) is one tool for generating such questions (Godhino, 2013). Here's a website that provides sample questions using Bloom's taxonomy: http://www.nmmu.ac.za/cyberhunts/bl oom.htm

c. Peers can hold discussions and can ask each other to elaborate on their statements.

4. Learning with peers: Students can interact with one another in a variety of ways as part of ER (Jacobs \& Gallo, 2002). Students can form reading groups (or literature circles) in which they select books to read together and discuss various aspects of the contents of the book, including the main characters of the story, the plot, serious and hilarious events, the ending and possible sequel. Benefits on peer interaction related to ER include:

a. Students can motivate each other to read more.

b. Students can offer each other suggestions of what to read or not read

c. Students can help each other understand what they are reading. 
They can also share specific strategies that they use to read faster and with deeper comprehension and greater enjoyment.

d. Discussing with peers can enhance student enjoyment of reading and can push them to think more deeply about what they read. As Freire (1970, cited in Crookes, 2013, p. 62) stated, "Only dialogue, which requires critical thinking, is also capable of generating critical thinking. Without dialogue there is no communication and without communication there can be no true education".

5. Diversity: Materials found by students, in hard copy or online, can add to the diversity of materials available for ER. Furthermore, when students share with peers about their reading, students gain exposure to new perspectives.

6. Connections to students' worlds: Students, with guidance from teachers, can create ER materials for themselves and peers (Dupuy \& McQuillan, 1997) or perhaps for younger or less proficient students (Rodgers, 1997). Student created materials can reflect students' immediate, localized concerns. Such materials (and teachers also can write ER materials, as explained below) enable students and their teachers to, following Freire (1970) and Crookes (2013), read and change their world as they read the words they and others in their class and school have written.

7. Teachers as fellow learners: Teachers too can contribute to the pool of ER materials. As with student generated materials, teacher generated ER materials need not be long or entirely original. Indeed, teacher generated works can be shorter than a page and can be adaptations (with proper attribution) of others' work. As teachers create materials, their writing and publishing skills improve.

8. Motivation and the self: To implement ER successfully, teachers are often seen as playing a central role in motivating their students to read. For instance, teachers model good reading habits and behaviors, make available interesting and relevant ER materials, and organize appealing post-reading activities. These are important, of course, but research suggests that when the source of motivation is internal, rather than external, students tend to become more committed in their learning (Taboada, Tonks, Wigfield, \& Guthrie, 2012). Research on L2 motivation (e.g., Hadfield \& Dornyei, 2013) suggests that students' intrinsic motivation may be bolstered when they are able to build and maintain a future self-image as successful L2 users. In the case of ER, students can be encouraged to:

a. build vivid and positive self-images of themselves as successful L2 readers

b. continually assess the gap between their actual selves and their ideal future selves

c. equip themselves with the knowledge and skills to narrow the gap between their actual selves and ideal selves

d. continually keep their ideal selves alive throughout the tenure of their studies.

A reading proficiency scale such as that developed by the Common European Framework of Reference for Languages (http://www.linguanet-europa.org/pdfs/selfassessment-grid-en.pdf) can be made available to students. This scale can help students assess their actual selves (which may presently be at the Basic Level of A1 or A2 readers) in relation to their ideal selves (which may be set at the Proficient Level of C1 or C2 readers). Students become more motivated in their learning when they know where they presently are and where they want to be at when they finish their studies.

\section{CONCLUSION}

This article began by situating extensive reading (ER) as one manifestation of a larger paradigm shift that has affected education and society generally. In education, one name for this shift is student centered 
learning (SCL). The second section of the article explained ways in which ER already incorporates features of the SCL paradigm. The final section suggested ideas that develop ER's SCL characteristics even further.

Change in education, such as the shift to SCL, does not come easily, as many education stakeholders still adhere to the formerly dominant paradigm, i.e., teacher centered learning (Fullan, 2007). Thus, ER and other manifestations of SCL must be implemented with ample forethought and perseverance. Due attention must be paid to matters such as selection, storage and marketing of reading materials, integration of ER with the rest of the curriculum, and student motivation to read in the short and long term. Successful ER implementation also includes explaining the rationale for ER to students, colleagues, administrators and other relevant stakeholders. Then, as ER is being implemented, frequent consultations with stakeholders can facilitate their support and their useful suggestions.

When the authors of this article first started teaching, we were very optimistic about using ER. We felt sure that our students would soon become enthusiastic readers in their second language. Our optimism was based on the fact that we had read the favorable research on ER, and we had experienced the benefits in our own first and second language learning. In addition, we expected that students would relish the control and the chance for meaningful language use that ER and SCL generally afford them. In short, we expected ER to be a big success. It was not. However, chastened by our initial, less than successful experiences with ER, and bolstered by advice from colleagues, we continue to implement ER and other SCL methods, and we continue to learn. As a result, our students more often enjoy ER. We look forward to continuing to learn about and share about ER, and we hope that you, the readers of this article, will join in the growing community of ER practitioners.

\section{REFERENCES}

Anderson, R. C. (1996). Research foundations to support wide reading. In V. Greaney (Ed.), Promoting reading in developing countries: Views on making reading materials accessible to increase literacy levels (pp. 55-77). Newark, DE: International Reading Association.

Ausubel, D.P. (1968). Educational psychology: A cognitive view. New York, NY: Holt, Rinehart \& Winston.

Bamford, J., \& Day, R. R. (Eds.). (2004). Extensive reading activities for language teaching. New York, NY: Cambridge University Press.

Banks, J. A., Cookson, P., Gay, G., \& Hawley, W. D. (2001). Diversity within unity: Essential principles for teaching and learning in a multicultural society. Phi Delta Kappan, 83(3), pp. 196-203.

Berman, M. (1981). The reenchantment of the world. Ithaca, NY: Cornell University Press.

Bloom, B. S., Engelhart, M. D., Furst, E. J., Hill, W. H., \& Krathwohl, D. R. (1956). Taxonomy of educational objectives: the classification of educational goals; Handbook I: Cognitive domain. New York, NY: Longman.

Boss, S. (2014). For engaging projects, connect learning to students' lives. Retrieved from http://www.edutopia.org/blog/studentengagement-pbl-suzie-boss

Brown, H. D. (2014). Principles of language learning and teaching ( $6^{\text {th }}$ edition). White Plains, NY: Pearson.

Burke, J. (n. d.). 103 things to do before/during/after reading. Retrieved from http://www.readingrockets.org/article/8 2

Capra, F. (1983). The turning point: Science, society, and the rising culture. Toronto, Canada: Bantam Books.

Carlisle, A. (2000). Reading logs: An application of reader-response theory in ELT. ELT Journal, 54(1), pp. 12-19. 
Cohen, E., \& Lotan, R. (2014). Designing groupwork: Strategies for the heterogeneous classroom (3rd ed.). New York: Teachers College Press.

Crookes, G. V. (2013). Critical ELT in action: Foundations, promises, praxis. New York, NY: Routledge.

Day, R. R. (2011, September). Bringing extensive reading into the classroom. Paper presented at the First Extensive Reading World Congress, Kyoto, Japan. Retrieved from http://www. youtube. com/watch? $v=y d j-U a R j h X Q$

Day, R. R., \& Bamford, J. (1998). Extensive reading in the second language classroom. Cambridge, England: Cambridge University Press.

Day, R. R., \& Bamford, J. (2002). Top ten principles for teaching extensive reading. Reading in a Foreign Language, 14(2), pp. 136-141.

Dornyei, Z., \& Ushioda, E. (Eds.). (2009). Motivation, language identity and the L2 self. Buffalo, NY: Multilingual Matters.

Du, F. (2012). Using study plans to develop self-directed learning skills: Implications from a pilot project. College Student Journal, 46(1), pp. 223232.

Dupuy, B., \& McQuillan, J. (1997).

Handcrafted books: Two for the price of one. In G. M. Jacobs, C. Davis \& W. A. Renandya (Eds.), Successful strategies for extensive reading (pp. 171-180). Singapore: SEAMEO Regional Language Centre.

Extensive Reading Foundation. (2011). Guide to extensive reading. Retrieved from http://erfoundation. org/ERF_Guide.pdf

Extensive Reading Foundation. (2014). Annotated bibliography of works on extensive reading in a second language. Retrieved from http://www.erfoundation. org/bib/biblio2.php

Feiman-Nemser, S. (2012). Teachers as learners. Cambridge, CA: Harvard Education Press.
Freire, P. (1970). Pedagogy of the oppressed. New York, NY: Seabury Press.

Fullan, M. (2007). The new meaning of educational change. New York, NY: Routledge.

Gardner, H. (1993). Multiple intelligences: The theory and practice. New York, NY: Basic Books.

Godhino, S. (2013). Helping your pupils to ask questions. London, England: Routledge.

Hadfield, J., \& Dörnyei, Z. (2013). Motivating learning. Harlow, England: Pearson.

Hill, H. C., Ball, D. L., \& Schilling, S. G. (2008). Unpacking pedagogical content knowledge: Conceptualizing and measuring teachers' topic-specific knowledge of students. Journal for Research in Mathematics Education, 39(4), pp. 372-400.

Jacobs, G. M., \& Farrell, T. S. C. (2001). Paradigm shift: Understanding and implementing change in second language education. TESL-EJ, 5(1). http://www. cc. kyoto-su. ac. jp/information/teslej/ej17/toc. html

Jacobs, G. M., \& Farrell, T. S. C. (2012). Teachers sourcebook for extensive reading. Charlotte, NC: Information Age Publishing.

Jacobs, G. M., \& Gallo, P. B. (2002).

Reading alone together: Enhancing extensive reading via student-student cooperation in second language instruction. Reading Online, 5(6). Retrieved from http://www. readingonline. org/articles/art_index. asp?HREF=jacobs/index.html

Jacobs, G. M., \& Kimura, H. (2013). Cooperative learning. In the series, English language teacher development. Alexandria, VA: TESOL.

Johnson, D. W., \& Johnson, R. T. (n.d.). Cooperative learning, values, and culturally

plural classrooms. Retrieved from http://www.brown.edu/academics/educati on-alliance/teaching-diverse- 
learners/sites/brown.edu.academics.educa tion-alliance.teaching-diverselearners/files/uploads/Cooperative\%20Le arning.pdf

Johnson, D. W., Johnson, R. T., \& Holubec, E. J. (2008). Circles of learning (8th ed.). Edina, MN: Interaction Book Company.

Kim, K. J. (2011). Reading motivation in two languages: An examination of EFL college students in Korea. Reading and Writing, 24(8), pp. 861-881. doi:http://dx.doi.org/10.1007/s11145010-9229-z

Knowles, M. S. (1975). Self-directed learning. New York, NY: Association Press.

Krashen, S. D. (2011). Free voluntary reading. Santa Barbara, CA: ABCCLIO.

Kuhn, T. S. (1962). The structure of scientific revolutions. Chicago, IL: University of Chicago Press.

Kuhn, T. S. (1996). The structure of scientific revolutions ( $3^{\text {rd }}$ ed.). Chicago, IL: University of Chicago Press.

Kumasi, K. (2014). Connected learning: Linking academics, popular culture, and digital literacy in a young urban scholars book club. Teacher Librarian, 41(3), pp. 8-15.

Maley, A. 2005. Review of "Extensive Reading Activities for the Second Language Classroom. ELT Journal, 59(4), 354-355.

Mason, B. (2006). Free voluntary reading and autonomy in second language acquisition: Improving TOEFL scores from reading alone. International Journal of Foreign Language Teaching, 2(1), pp. 2-5.

Mayr, W. B. (2012). Creating a heritage trail through self-directed learning in the foreign language classroom. The Journal of Linguistic and Intercultural Education, 5, pp. 67-94

Ministry of Education Singapore. (2010). MOE to enhance learning of 21st century competencies and strengthen art, music and physical education. Retrieved from http://www. moe. gov. sg/media/press/2010/03/moe-toenhance-learning-of-21s. php

O'Shea, L. J., Sindelar, P. T., \& O'Shea, D. J. (1985). The effects of repeated readings and attentional cues on reading fluency and comprehension. Journal of Literacy Research, 17(2), pp. 129-142.

Renandya, W. A. (2007). The power of extensive reading. RELC Journal, 38, pp. 133-149.

Renandya, W.A. (2014). Motivation in the language classroom. Alexandria, VA: TESOL.

Rodgers, T. (1997). Partnerships in reading and writing. In G. M. Jacobs, C. Davis \& W. A. Renandya (Eds.), Successful strategies for extensive reading (pp. 120-127). Singapore: SEAMEO Regional Language Centre.

Taboada, A., Tonks, S. M., Wigfield, A., \& Guthrie, J. T. (2009). Effects of motivational and cognitive variables on reading comprehension. Reading and Writing, 22(1), pp. 85-106.

Torres, G. (2013). Empowering the language learner: Language learning strategy training and self-regulation in an EFL classroom. Journal of International Education Research, 9(3), pp. 267-276.

Tseng, W. T., Dornyei, Z., \& Schmitt, N. (2006). A new approach to assessing strategic learning: The case of selfregulation in vocabulary acquisition. Applied Linguistics, 27, pp. 78-102. 